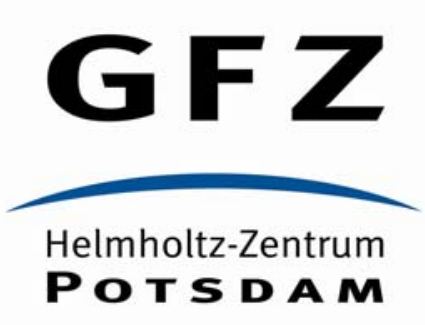

Originally published as:

Pierdominici, S., Heidbach, O. (2012): Stress field of Italy - Mean stress orientation at different depths and wave-length of the stress pattern. - Tectonophysics, 532-535, 301-311

DOI: 10.1016/j.tecto.2012.02.0 


\title{
Stress field of Italy - Mean stress orientation at different depths and wave-length of stress pattern
}

\author{
Simona Pierdominici*, Oliver Heidbach \\ Helmholtz Zentrum Potsdam, Deutsches GeoForschungsZentrum GFZ, Germany
}

A R T I C L E I N F O

Article history:

Received 6 July 2011

Received in revised form 9 February 2012

Accepted 14 February 2012

Available online 24 February 2012

Keywords:

Stress pattern

Wave-length analysis

Tectonic stress

Stress sources

Italy

\begin{abstract}
A B S T R A C T
We have studied the stress pattern of Italy using a dataset with 590 data records from the World Stress Map database release 2008 and 106 new data records to test the hypothesis the mean orientation of maximum horizontal stress $S_{H}$ is different at different depth sections. For this, we split the dataset into a shallow $(0-6 \mathrm{~km})$ and a deep (6-40 km) depth section. For the data analysis we used a new statistical tool that calculates the mean $S_{H}$ orientation on a $0.2^{\circ}$ grid. The tool takes into account the distance to each grid point, number and quality of the data records within the search radius, and the radial distribution. The result is a smoothed Italian stress map that displays both; the mean $S_{H}$ orientation and the wave-length of the stress pattern. The stress pattern does not vary in depth except for two areas (Sardinia and southern Apulia). Therefore stress data from different depths can be used to estimate the mean $S_{H}$ orientation and the wave-length of the stress pattern in Italy. Furthermore, the smoothed Italian stress map reveals that most of Italy has short wave-length stress patterns $(<150 \mathrm{~km})$. This indicates that the stress field is not controlled by first-order stress sources of plate tectonics, i.e. the convergence of Africa with respect to Eurasia, but that second-order stress sources such as topography, density, strength contrasts, and major faults systems are of great importance. In four regions (western part of the Alps, northern Tuscany, northern Adriatic Sea, Calabria and eastern part of Sicily) the wave-length is $<100 \mathrm{~km}$. High values of the circular variance of the mean $S_{H}$ orientation observed here are driven by third-order local stress sources, such as basins or local neotectonic structures.
\end{abstract}

\section{Introduction}

Knowledge of the in situ contemporary stress state is of great importance e.g. for seismic hazard assessment, hydrocarbon and geothermal reservoir management, nuclear waste disposal and subsurface $\mathrm{CO}_{2}$ storage (Fuchs and Müller, 2001). On a smaller scale the in situ stress state is important to predict wellbore stability and mitigate the risks of hydraulic fracturing (e.g Bell, 1996; Tingay et al., 2005). The global resource for stress data is the World Stress Map (WSM; www.world-stressmap.org) that provides a database of present-day stress field information of the Earth's crust (Heidbach et al., 2010; Sperner et al., 2003; Zoback, 1992; Zoback et al., 1989). In particular the WSM compiles the orientation of maximum horizontal compressive stress $\left(S_{H}\right)$ that is derived from a wide range of stress indicators such as earthquake focal mechanism solutions, drillinginduced fractures, borehole break-outs, hydraulic fracturing overcoring as well as geologic data from seismogenic fault-slip analysis and volcanic vent alignments. The stress information is compiled in a standardized data format and quality-ranked in order to be comparable (Heidbach et al., 2010; Zoback, 1992; Zoback and Zoback, 1989,1991). However, the various stress indicators reflect the in situ stress of very different rock volumes ranging from $10^{-3}$ to $10^{9} \mathrm{~m}^{3}$ (Ljundgren et al., 2003). Geological indicators, overcoring data, focal mechanism of earthquakes, drilling-induced fractures, hydraulic fracturing borehole breakout data probe the stress patterns within the upper $6 \mathrm{~km}$ of the Earth's crust (Bell and Gough, 1979; Plumb and Cox, 1987; Zang and Stephansson, 2010; Zoback and Zoback, 1980, 1991; Zoback et al., 1985, 1989) with bore-hole breakouts as a major contributor. In the deeper crust below $6 \mathrm{~km}$, earthquake focal mechanism solutions are the only available stress indicators, except borehole breakouts from a few deep drillings (Brudy et al., 1997; Heidbach et al., 2004; Zang and Stephansson, 2010; Zoback, 1992). The most common visualization of the WSM database is through stress maps where data from depths

\footnotetext{
* Corresponding author at: Helmholtz Zentrum Potsdam, Deutsches GeoForschungsZentrum GFZ, Germany. Formerly at Istituto Nazionale di Geofisica e Vulcanologia, Italy.

E-mail address: pierdo@gfz-potsdam.de (S. Pierdominici).
}

between 0 and $40 \mathrm{~km}$ is integrated (Heidbach and Höhne, 2008; Heidbach et al., 2004; Zoback et al., 1989) assuming that the $S_{H}$ orientation does not change significantly with depth. This assumption was tested qualitatively at the beginning of the WSM project (Zoback, 1992), but a rigorous statistical test of this assumption was not performed due to insufficient data coverage.

For our analysis we use the stress dataset of Italy to test whether the stress pattern at shallow depth $(<6 \mathrm{~km})$ is similar to the one at greater depth $(\geq 6 \mathrm{~km}$ ). The Italian dataset is optimal to test the hypothesis for two reasons: first, the density of high quality data records is one of highest world-wide; the Italian dataset we use contains 590 data records from the WSM 2008 database release and 106 new Italian data records compiled for this study. Second, and more important, the amount of shallow borehole breakout data in Italy is exceptionally high $(n=331)$ and comparable to the number of data from earthquake focal mechanism solutions $(n=356)$.

The stress pattern of Italy has been investigated in great detail by Montone et al. (2004) applying the smoothing algorithm of Müller et al. (2003) to estimate the mean $S_{H}$ orientation on a regular grid. Here, we will use an improved version of that smoothing algorithm as reported by Heidbach et al. (2010). This improved version allows us to determine both, the mean $S_{H}$ orientation and its circular variance on a regular grid as well as the wave-length of the stress pattern. Furthermore, we improved the statistical analysis of Heidbach et al. (2010) to account for the high difference of stress data record density in onshore and off-shore areas.

In the following chapters we first present an overview on the updated Italian stress dataset and present the basics of the statistical method as well as its improvements. We then discuss the results of the statistical analysis and present the interpretation in terms of patterns of the mean $S_{H}$ orientation and the tectonics.

\section{The Italian stress dataset}

For this study we compiled an updated Italian stress dataset based on the WSM database release 2008 which contains 590 
stress data entries for Italy (Heidbach et al., 2010). To this dataset we added 106 new data records thus having a total of 696 stress data records providing a reliable information on the $S_{H}$ orientation (Fig. 1).

78 of the new data records derive from focal mechanism solutions from earthquakes (http://www.bo.ingv.it/RCMT/ searchRCMT.html; Pondrelli et al., 2011) located in central Italy (39 data records), southern Apennines (27 data entries) and northern Italy (12 data), all from a depth range between 2 and $40 \mathrm{~km}$. 28 new Italian data records come from borehole breakouts of which 25 wells are located in southern Apennines (Barba et al., 2010; Pierdominici et al., 2011; Montone et al., 2012) and 3 boreholes in central Apennines (Mariucci et al.,
$2008,2010)$. The depth range of breakout intervals is between $450 \mathrm{~m}$ and $5585 \mathrm{~m}$.

We have also revised the shallow depth of the focal mechanism solutions listed in the WSM database release 2008 using the information of different seismic Catalogues (CSI http:// csi.rm.ingv.it/; CENEC http://dx.doi.org/10.2312/GFZ.CENEC2008; NEIC http://earthquake.usgs.gov/regional/neic/; SED http://www.seismo.ethz.ch/). These data provide new depth information for 58 events.

To each data record a quality is assigned. The qualities range from A (the best) to E (the worst) following the updated WSM quality ranking scheme (Heidbach et al., 2010). A-quality indicates that the $S_{H}$ orientation is reliable within $\pm 15^{\circ}$, B-quality

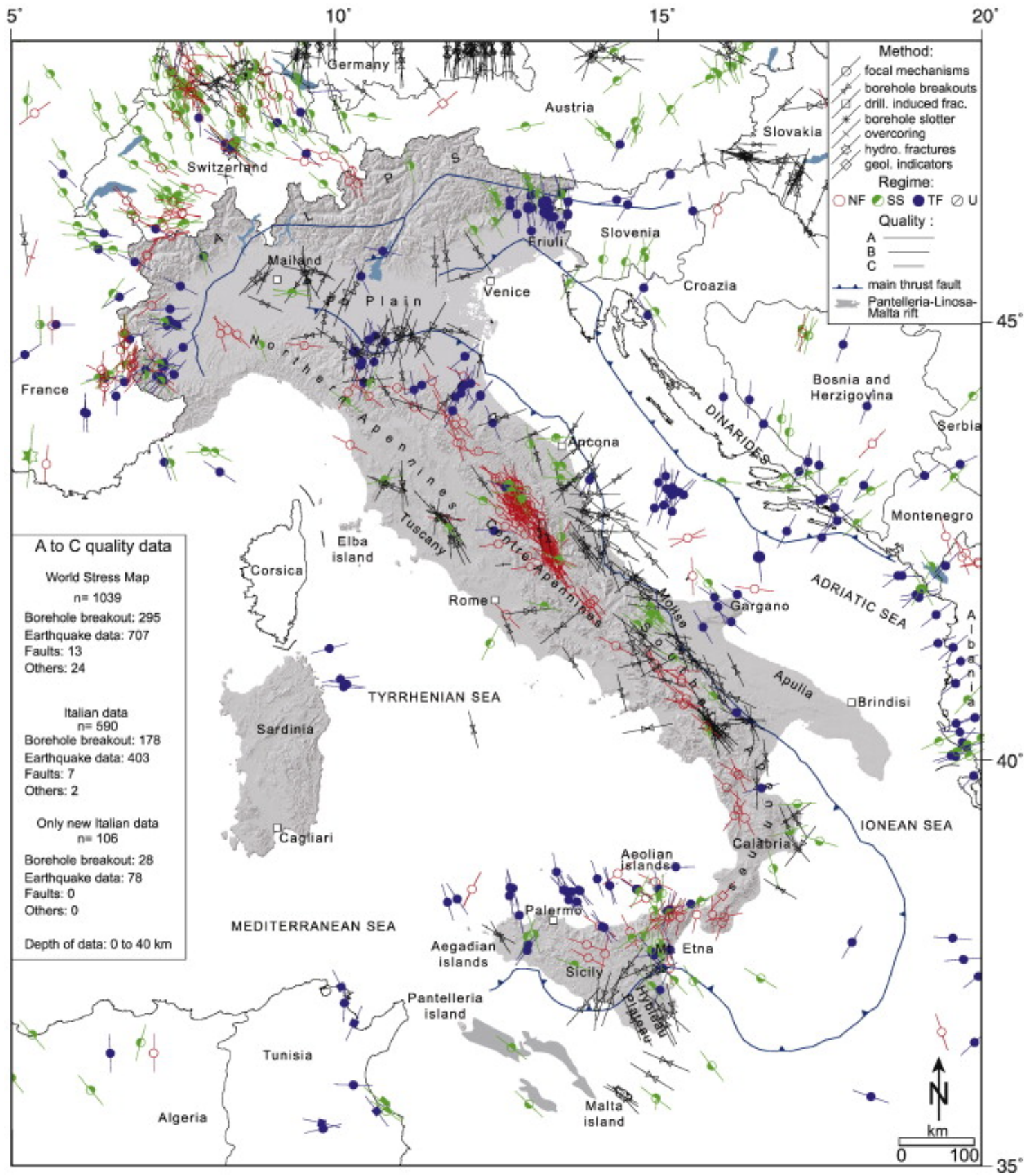

Figure 1. Stress map of Italy based on the A-C quality data records from the WSM database release 2008 (Barba et al., 2010; Heidbach et al., 2008, 2010; Mariucci et al., 2008, 2010; Montone et al., 2012; Pierdominici et al., 2011; Pondrelli et al., 2011). The orientations of maximum horizontal compression $\left(\boldsymbol{S}_{H}\right)$ for depth 0-40 km are shown. See inset legend for details on data types, stress regime $(\mathrm{NF}=$ normal faulting, $\mathrm{SS}=$ strike-slip, $\mathrm{TF}=$ thrust faulting, $\mathrm{U}=$ undefined), and quality ranking. The symbol of data is proportional according to the quality ranking (Heidbach et al., 2008). Three tectonic regimes are still active: i) the normal faulting regime as inferred from focal mechanism solutions is prevalent along the Apennine belt and in the western part of Alps; ii) the eastern part of the Alpine chain, the foredeep and foreland Apennine belt and the northern part of Sicily are characterized by thrust faulting particularly from focal mechanism solutions, iii) and strike-slip regimes mainly in eastern part of the Alps, close to Ancona town, Molise area and Sicily island. 
within $\pm 20^{\circ}$, C-quality within $\pm 25^{\circ}$, D-quality within $\pm 40^{\circ}$ and Equality with an error larger than $\pm 40^{\circ}$ or insufficient information to derive the $S_{H}$ orientation. For this study we use only A-C quality data records as these are considered reliable for the interpretation of geodynamic and deformation processes in the lithosphere (Heidbach et al., 2010; Zoback, 1992).

The spatial distribution of stress data in Italy is quite homogeneous over the entire area except for Sardinia and the southern Apulia region where less data are available (Figs. 1 and 2). We subdivided Italy in 23 subregions (each $2.5^{\circ}$ longitude and $2.5^{\circ}$ latitude) to quantify the spatial distribution of A-C quality data records. Orange and red shade colors in Fig. 2a demonstrate a high number of data ( $>40$ data) in 6 subregions which cover most of the Italian territory.

The majority of the data records in Italy are from earthquake focal mechanism solutions (68.3\%) and borehole breakout data $(30.2 \%)$. A small contribution comes from faults $(1.2 \%)$ and overcoring (0.3\%; Fig. 3a). C-quality data are prevalent (85.4\%) compared with B- and A-quality data records with a $12.7 \%$ and a $1.9 \%$, respectively (Fig. $3 \mathrm{~b}$ ). About half of the data records indicate normal faulting regime (48.5\%), 31.5\% thrust faulting regime and $20 \%$ strike-slip regime (Fig. 3c).

The earthquake focal mechanism solutions are most concentrated along the Apennine belt and an active tectonic region comprising the far western and eastern part of the Alpine chain and the southern subduction zone (Fig. 1) with a depth distribution between 0 and $40 \mathrm{~km}$. Approximately $95 \%$ of the data records derived from earthquakes focal mechanism solutions are located at depths between 6 and $40 \mathrm{~km}$ (Fig. 4). The borehole breakout records (depth from 0 to $6 \mathrm{~km}$; Fig. 4) are clustered due to the presence of the deep wells drilled for hydrocarbon prospective in i) the Po Plain, ii) the Adriatic Sea and northern off-shore of Sicily, iii) the southern Apennine fore-deep and iv) some intramountain basins. Data from active faults (late Quaternary-Holocene) mainly derived from Apennine belt, whereas few deep overcoring data are located in Sicily.

From these regions, three tectonic regimes are still active. The normal faulting regime is inferred from earthquake focal mechanism solutions and it is prevalent along the Apennine belt, in the western part of the Alps and in northern and eastern Sicily (Fig. 1). On the contrary, the eastern part of the Alpine chain, the foredeep and foreland Apenninic belt and the northern off-shore of Sicily are prevalent characterized by a compressional regime particularly from focal mechanism solutions (Fig. 1).

\section{Statistical analysis}

\subsection{Smoothing procedure}

To investigate the sources of the stress field the wavelength of the stress pattern is a good indicator. Plate-wide wavelength of the stress pattern indicate that plate boundary forces govern the stress pattern, whereas shorter wavelength indicates that regional or local stress sources from topography or active fault systems are also major stress sources (Coblentz and Richardson, 1995; Heidbach et al., 2007; Zoback, 1992; Zoback et al., 1989). Müller et al. (2003) presented a tool to estimate the mean $S_{H}$ orientation on a regular grid using a pre-defined constant search radius to discriminate between local and regional trend in the $S_{H}$ orientation. Data records within the search radius are weighted according to their distance to the grid point and the quality of the data record (Montone et al., 2004; Müller et al., 2003; Reinecker et al., 2010). However, this approach does not provide a measure for the reliability of the estimated mean $S_{H}$
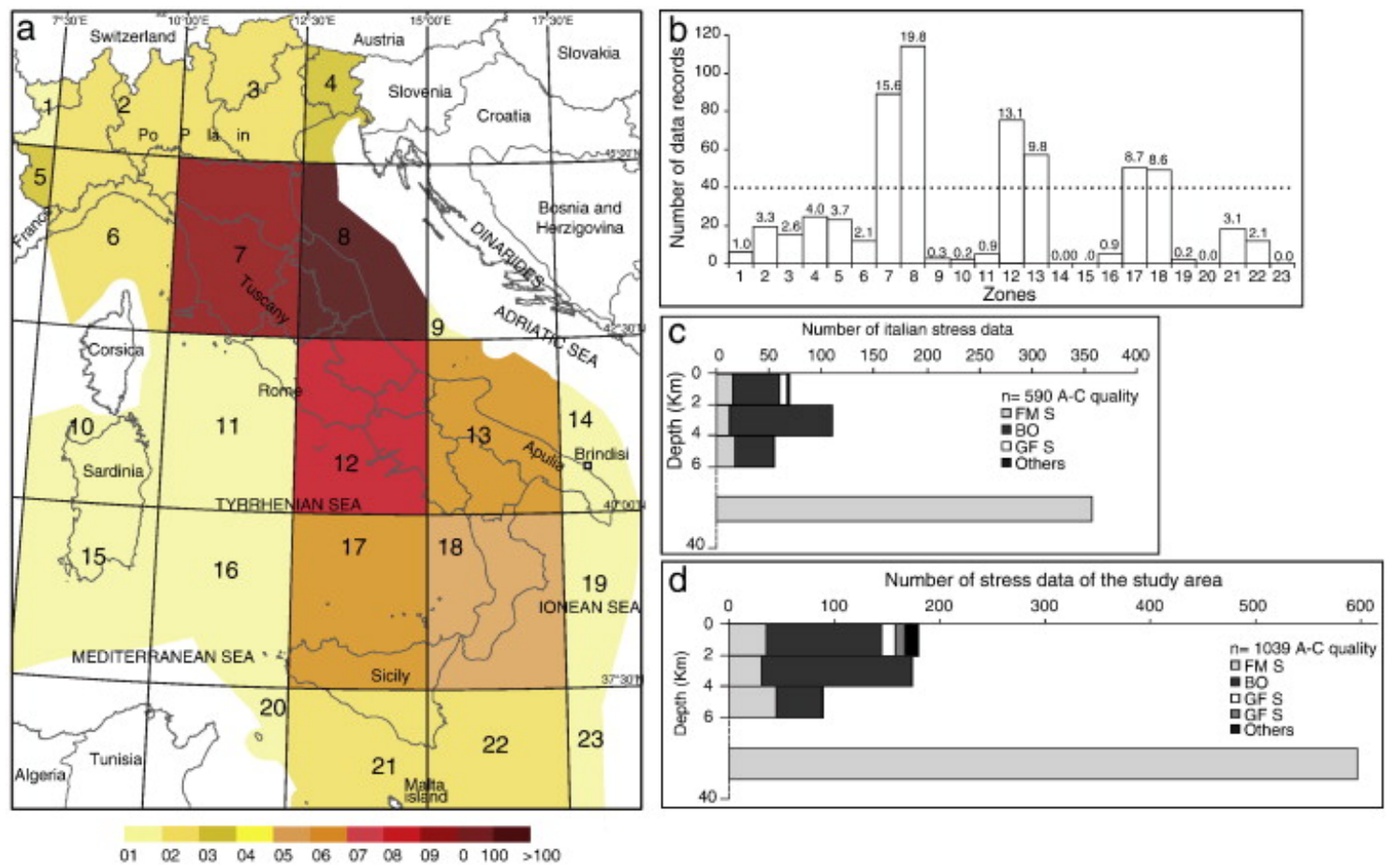

Figure 2. a) The areal distribution of contemporary stress data records in Italy. We have subdivided the Italian territory in 23 subregions and we have counted the number of data in each subregion. The scale of colors from light yellow ( $<10$ data) to brown ( $>100$ data) represents the number of stress data records. b) Six subregions each have more than 40 data entries covering the most part of Italy (shaded black line). The number above each bin indicates the percent of data in each region compare to the total amount ( 590 data). The highest number of data is in the subregion $\mathrm{n}$. 8 that includes a high concentration mainly of earthquakes and borehole breakouts. 9 subregions (of which 6 in offshore of Italy) have less than 10 data entries. The figure shows an areal distribution of contemporary stress data records quite homogeneous over the entire area except for Sardinia island (sub-regions n. 10 and n. 15) and the southern Apulia region (subregion n. 14). The diagram shows the depth distribution of stress entries in Italy c) and in the entire study area (d). Both plots show that the geological indicators, overcoring data, drilling-induced fractures, hydraulic fracturing and borehole breakout data are prevalent within the upper $6 \mathrm{~km}$ of the Earth's crust. On the contrary, the earthquakes focal mechanisms prevail at deeper crust (below $6 \mathrm{~km}$ ). 


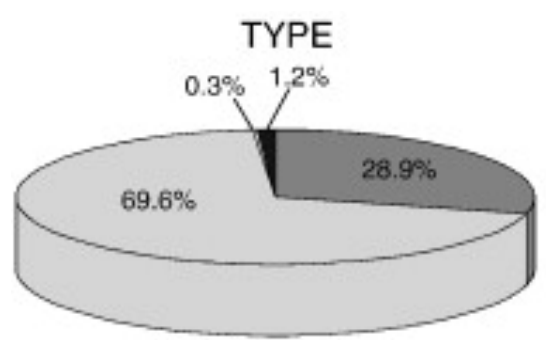

$\square F M S G \square B O$

FS $\square$ OC

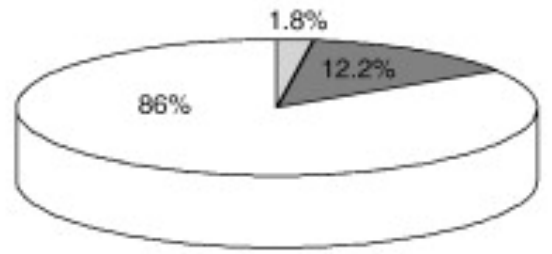

$\square \mathrm{A} \square \mathrm{B} \square \mathrm{C}$
TECTONIC REGIME

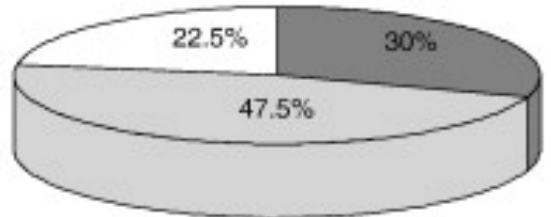

$\square N F \quad \square T F S$

Figure 3. Pie-chart calculated from $\mathrm{A}$ to $\mathrm{C}$ quality ranking data consideration for type, quality and tectonic regime of data records, prevailing the focal mechanism solutions (69.6\%); C-quality data (86\%) and normal fault regime (47.5\%), respectively. Legend: "Type of data" OC = overcorings, FMS = focal mechanism solutions, $\mathrm{BO}=$ borehole breakouts, GFS = geological fault systems; "Quality" A = highest, B = high, C = intermediate; "Tectonic Regime" NF = normal faulting, $\mathrm{SS}=$ strike-slip faulting, $\mathrm{TF}=$ thrust faulting.
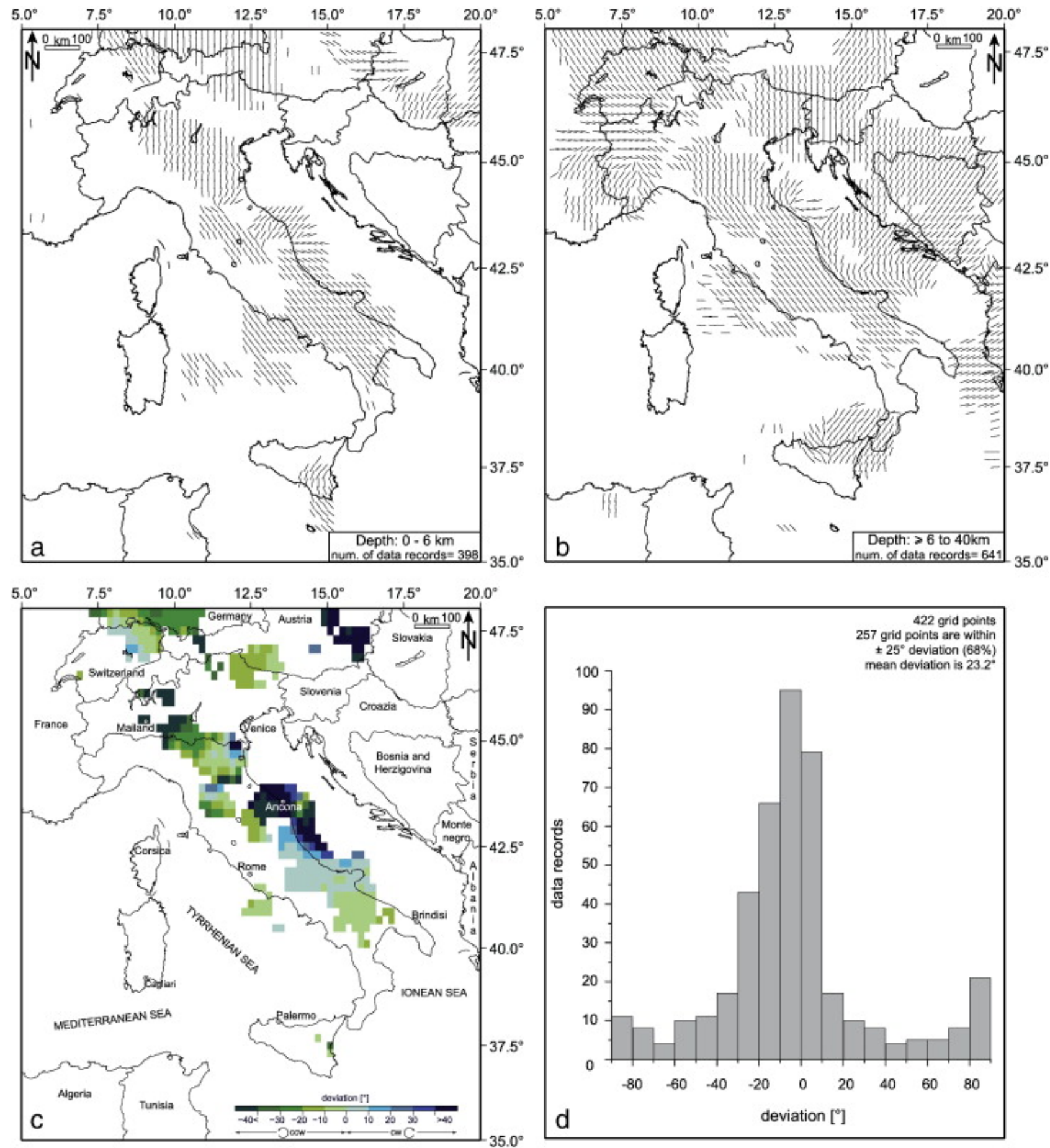

Figure 4. Statistical analysis of the mean $\boldsymbol{S}_{\boldsymbol{H}}$ orientation on a $0.2^{\circ}$ grid. (a) Based on A-C quality with depth b6 km (b) Based on A-C quality with depth $\geq 6 \mathrm{~km}$ depth. (c) Deviation between mean $\boldsymbol{S}_{\boldsymbol{H}}$ orientation from shallow data and deep data at common grid points. (d) Histogram of the deviation distribution. 
orientation, i.e. the circular variance $S_{G}$ of the mean $S_{H}$ orientation is not taken into account. In areas where the mean $S_{H}$ orientation changes on short spatial scales, a large search radius would produce a high circular variance. As a consequence the resulting mean $S_{H}$ orientation would be less reliable. To improve the smoothing tool of Müller et al. (2003), Heidbach et al. (2010) use for each grid point variable search radii. The search radius starts with $1000 \mathrm{~km}$ and then decreases stepwise until the circular variance $S_{G}$ of the mean $S_{H}$ orientation is below a given threshold value, e.g. $S_{G}<25^{\circ}$. The corresponding search radius $r_{\text {max }}$ is also stored for each grid point as it reflects the wave-length of the stress pattern at this point. For the computation of the mean $S_{H}$ orientation the stress data are weighted by their assigned quality with $w_{Q}=1 / 15$ for A-quality data, $w_{Q}=1 / 20$ for B-quality data and $w_{Q}=1 / 25$ for C-quality data as well as by their inverse distance to the grid point with $w_{D}=\min (1 / D, 1 / 10) \mathrm{km}$, where $D$ is the distance between the data location and the grid point. The minimum value of $w_{D}=10$ $\mathrm{km}$ that is allowed for the distance weight is necessary in order to avoid an over-representation of data records that are located close to the grid point during calculation of the mean $S_{H}$ orientation.

Following Mardia (1972) the mean $S_{H}$ orientation results from the single azimuths $\theta_{i}$ of the $N$ data records located within the search radius using the following relation $\left(\theta_{i} \in\left[0^{\circ}, 180^{\circ}\right]\right)$ :

mean $S_{H}=\frac{\arctan 2(\bar{S}, \bar{C})}{2} \bmod 180^{\circ}$

with

$w_{i}=w_{Q} w_{D}$

$\bar{C}=\frac{1}{Z} \sum_{i=1}^{N} w_{i} \cos 2 \theta_{i}$

$\bar{S}=\frac{1}{Z} \sum_{i=1}^{N} w_{i} \cos 2 \theta_{i}$

$Z=\sum_{i=1}^{N} w_{i}$

Using $\bar{R}=\sqrt{\bar{C}^{2}+S^{2}}$, the circular variance $S_{G}$ is

$S_{G}=\frac{\sqrt{-2 \log _{e} \bar{R}}}{2} \cdot \frac{180^{\circ}}{\pi}$.

Here we apply the approach of Heidbach et al. (2010) for the first time on a regional stress dataset. For our study we request that the minimum number of data records needs to be $n \geq 10$ within the search radii to compute the mean $S_{H}$ orientation, the circular variance $S_{G}$ and the search radius $r_{\max }$ when the threshold of the circular variance is reached. Furthermore, to account for the sharply decreasing data density between onshore and off-shore areas it is also mandatory that data within the search radius must be located in at least two diagonal quadrants of the search circle around the grid point. This guarantees that onshore data e.g. from the west Italian coast are not extrapolated to large offshore areas (towards the Tyrrhenian Sea) where no stress data is available. To avoid boundary effects the smoothing area is larger than the study area (latitude $35^{\circ}$ to $48^{\circ}$ and longitude $5^{\circ}$ to $20^{\circ}$ ) by means of 1039 A-C data records from neighboring areas and Italy. We decrease the search radius from $1000 \mathrm{~km}$ in steps of $50 \mathrm{~km}$ and apply the approach on a $0.2^{\circ}$ grid. This procedure results in the quantification of the appropriate search radius and the mean $S_{H}$ orientation and $S_{G}$.
As result we receive a smoothed Italian stress map that displays both: the mean $S_{H}$ orientation on a $0.2^{\circ}$ grid and the wavelength of the stress pattern.

\subsection{Mean $S_{H}$ orientation at different depth layers}

To test the hypothesis of consistent stress pattern at different depth we split the dataset in two different depth sections $(<6 \mathrm{~km}$ and $\geq 6 \mathrm{~km}$ ). The division at $6 \mathrm{~km}$ is chosen due to the maximum depth of borehole breakout data from the study area, limited by the maximum borehole depth $(5.9 \mathrm{~km})$. Below $6 \mathrm{~km}$ depth earthquake focal mechanism are the only available stress indicators. Most of earthquake focal mechanisms are localized below $6 \mathrm{~km}(\sim 640$ data records with A-C quality) while only a few are located in the shallow part of the crust $(<6 \mathrm{~km}, \sim 65$ data records with A-C quality). We compare the stress data from drillable depths with data from focal mechanisms below drillable depth and apply the smoothing tool as described in Section 3.1.

The analysis of the mean $S_{H}$ orientation on a regular grid reveals a very good coherence of the mean $S_{H}$ orientation between both data-sets along the peninsula, particularly along the Apennines belt and in the middle of Po Plain (Fig. 4). Overlapping areas are not present in Sicily because the breakout data are concentrated in south-eastern part of the island (Hyblean plateau) while the focal mechanism solutions are mostly situated in the north. Therefore, a comparison of the mean $S_{H}$ orientation from different depth is not possible. In the other areas the consistency between shallow and deeper mean $S_{H}$ orientation data is surprisingly well. This indicates that upper and lower part of the crust is very much likely mechanically coupled and the assumption of little variation of the $S_{H}$ orientation with depth is valid at least for Italy. We also tested if the very shallow data with depth b500 m, where more scatter is expected have an impact on this result. However, the effect is very small.

The good correlation is also confirmed by the histogram of the deviation between the mean $S_{H}$ orientation from shallow data vs. deep data on common grid points (Fig. 4d). The mean deviation of the 422 grid points where mean $S_{H}$ orientations are available from both depth section is $23.2^{\circ}$. $68 \%$ of the common grid points show a deviation of $<25^{\circ}$ which is smaller than the uncertainty of most the stress data records.

The deviation distribution is also shown in a color code (Fig. 4c). The central-southern and northern Apennines exhibit a generally small deviation within $20^{\circ}$. Areas of high deviation are off-shore in the Adriatic Sea and the western part of Po Plain. In the Po Plain the deep data from focal mechanism show a NS mean $S_{H}$ orientation (Fig. $4 \mathrm{~b}$ ) whereas the mean $S_{H}$ orientation data deriving from shallow depth reveals a fan-shaped stress pattern that rotates from NW in the West to a NE in the East. This indicates that in the Po Plain the stress pattern at depth has a longer wave-length than the shallow stress pattern.

The reason for the deviation between the deep and shallow $S_{H}$ orientation offshore in the Adriatic Sea is different. The stress pattern of the deep data shows the long-wave length of the NNW trend of the mean $S_{H}$ orientation from the Apennines region. For the deep data this trend is extrapolated into the coastal region and offshore even though very few data from $\geq 6 \mathrm{~km}$ depth are available in the off-shore region. However, at shallow depth lots of data are available in the coastal region from shallow depth $<6 \mathrm{~km}$, but showing a mean $S_{H}$ orientation that is rotated by almost $90^{\circ}$ which produces high deviations in that region. Both, the Po Plain region and the offshore region in the Adriatic Sea are discussed in more detail in chapter 5 .

Nevertheless, the overall deviation of distribution agrees well between deep and shallow mean $S_{H}$ orientations. This result implies that for most regions in Italy the mean $S_{H}$ orientation, derived from earthquake focal mechanism solutions at depth $<6 \mathrm{~km}$, is consistent with the mean $S_{H}$ orientations derived from borehole data. In particular these results confirm the 
hypothesis. Thus, data records from all depth sections $(0-$ $40 \mathrm{~km}$ ) can be used for the estimation of the mean $S_{H}$ orientation on a regular grid and the analysis of the wave-length of the stress pattern.

\subsection{Mean $S_{H}$ orientation and wave-length of the stress pattern}

The result of the mean $S_{H}$ orientation using data records from $0-40 \mathrm{~km}$ depth on a $0.2^{\circ}$ grid is displayed in Fig. 5. In most areas the wave-length pattern is short $\left(r_{\max }<150 \mathrm{~km}\right)$ except for the southern and central Apennines as well as for the northeastern area of Italy where the wave-length is intermediate with $r_{\text {max }}$ between 150 and $350 \mathrm{~km}$. The smoothed stress field of the mean $S_{H}$ orientation is similar with the smoothed stress field reported by Montone et al. (2004). A homogeneous NW-SE mean $S_{H}$ orientation governs central Italy, while in northern Italy and in Sicily the mean $S_{H}$ orientations are considerably scatter probably due to the present-day activities of several tectonic structures with different orientation and stress regimes. The short wave-length of the Italian stress pattern (light blue color) is associated with regional to local stress sources linked to the presence of basin geometry, topography and active faults (second-and third order of stress pattern). These effects overrule the stress sources from plate boundary forces (first-order stress pattern). Fig. $5 \mathrm{~b}$ shows the variance of the mean $S_{H}$ orientations. The area with lowest circular variance (green color) is located along the Apennines belt (where the number and quality of data is robust) while the high values (red color) are present in four zones (c.f. number 1 to 4 in Fig. 5b). Some contrasting results, e.g. high variance of the mean $S_{H}$ orientations, were obtained from the contemporary stress data records. These findings demonstrate a very complex pattern characterized by inhomogeneous orientations related to a non-uniform stress field, probably correlated with the complex tectonic setting of these areas (Fig. 5). Some contrasting results in terms of variance of the mean $S_{H}$ orientations were obtained from the contemporary stress data records in the study area. The results, in terms of the mean $S_{H}$ orientations and its circular variance, show a very complex pattern characterized by inhomogeneous orientations related to a non-uniform stress field.

A map of the mean $S_{H}$ orientation with the major neotectonic structures clearly shows the correlation between recent tectonic activity and re-orientation of the mean $S_{H}$ orientation (Fig. 6). In this framework, we distinguish a prevalent regional stress pattern with $\mathrm{NE}$ orientation along the Apenninic belt consistent with the normal faults. The eastern Alps and the Po Plain area have been affected by a $\sim$ NS and NNE-SSW trend of the mean $S_{H}$ orientation and associated to active compressive tectonic structures. These areas exhibit a local stress pattern (third-order) due to high variability in the mean $S_{H}$ orientations indicated also by the high circular variance (Fig. 5). Further details of the stress source of these area are widely discussed in the following section.

\section{Discussion}

The present-day structural setting of Italy is the result of the convergence of the main plates of Eurasia, Adria and Africa that has initiated tectonic processes of continental collision, slab rollback, back-arc basin formation and oceanic subduction in our study area (e.g. Anderson and Jackson, 1987; Boccaletti and Dainelli, 1982; Calais et al., 2003; Devoti et al., 2008; Dewey et al., 1973, 1989; Faccenna et al., 1996, 2003; Mazzoli and Helman, 1994; Malinverno and Ryan, 1986). The Alpine chain is the result of oceanic subduction and following collision (late Mesozoic and early Tertiary) whereas the Apennine belt is connected to the subduction of oceanic lithosphere (e.g., Chiarabba et al., 2008; Di Stefano et al., 2009; Faccenna et al., 2004). The Calabrian Arc is the only area within the Tyrrhenian-Apennine system that still consumes oceanic lithosphere (Chiarabba et al., 2005, 2008; Cimini and Marchetti, 2006; Rosenbaum and Lister, 2004; Selvaggi and Amato, 1992). In contrast, there is no evidence for active subduction in the central-southern Apennines, (e.g., Di Stefano et al., 2009; Meletti et al., 2000; Rosenbaum and Lister, 2004). In this context, we discuss the result of the statistical analysis, including mean $S_{H}$ orientation, wave-length stress pattern and its associated circular variance in the context of the
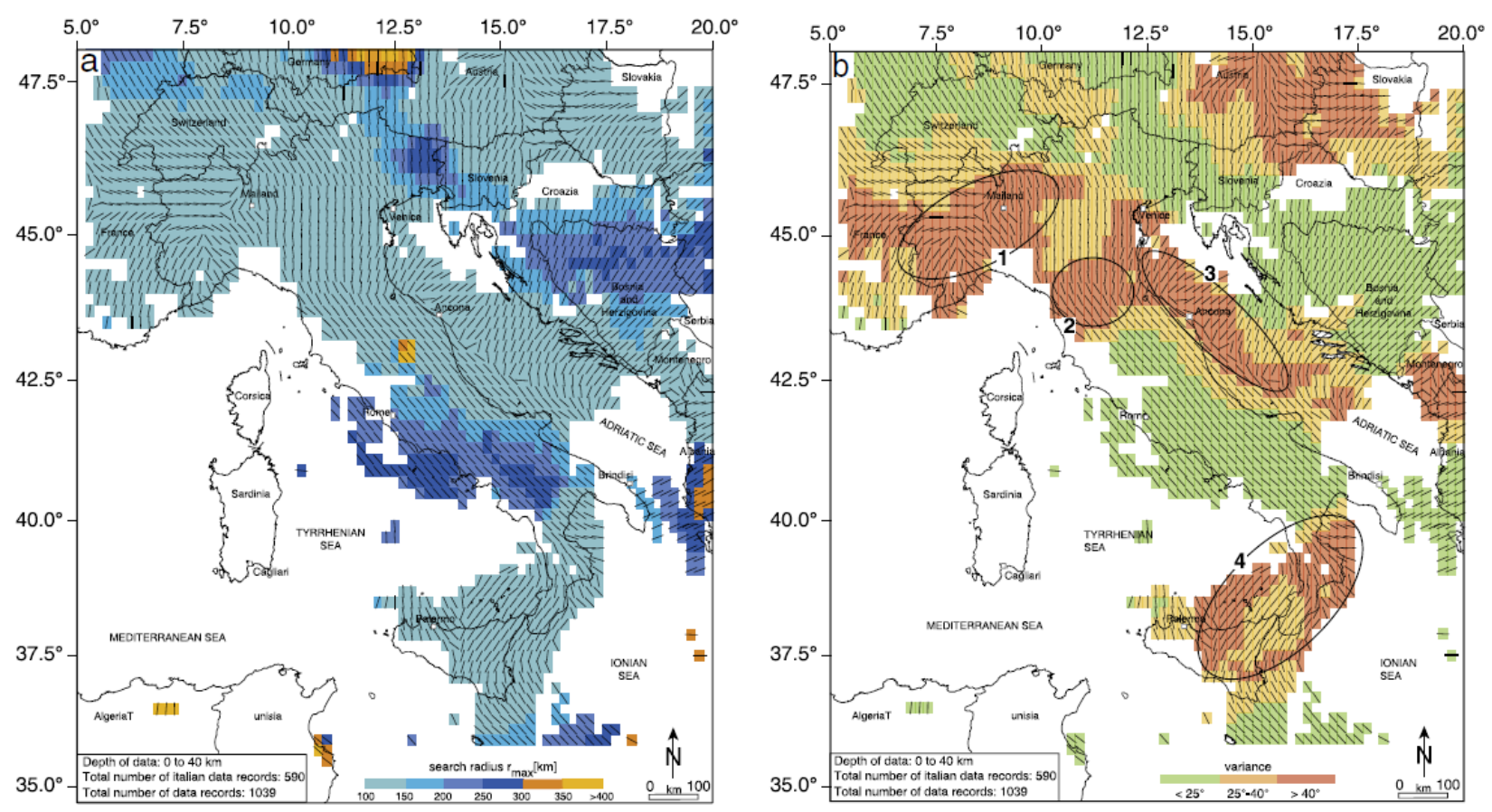

Figure 5. a) Smoothed stress map of Italy that displays: the mean $S_{H}$ orientation and $r_{\max }$ (maximum search radius with the standard deviation for each grid point with a given mean $S_{H}$ orientation is less than $25^{\circ}$ ). The stress pattern shows a prevalent short wave-length (blue-light blue color); b) variance of the mean $S_{H}$ orientations: low (green color), intermediate (orange color) and high (red color). The four high variance zones are marked by circles. 


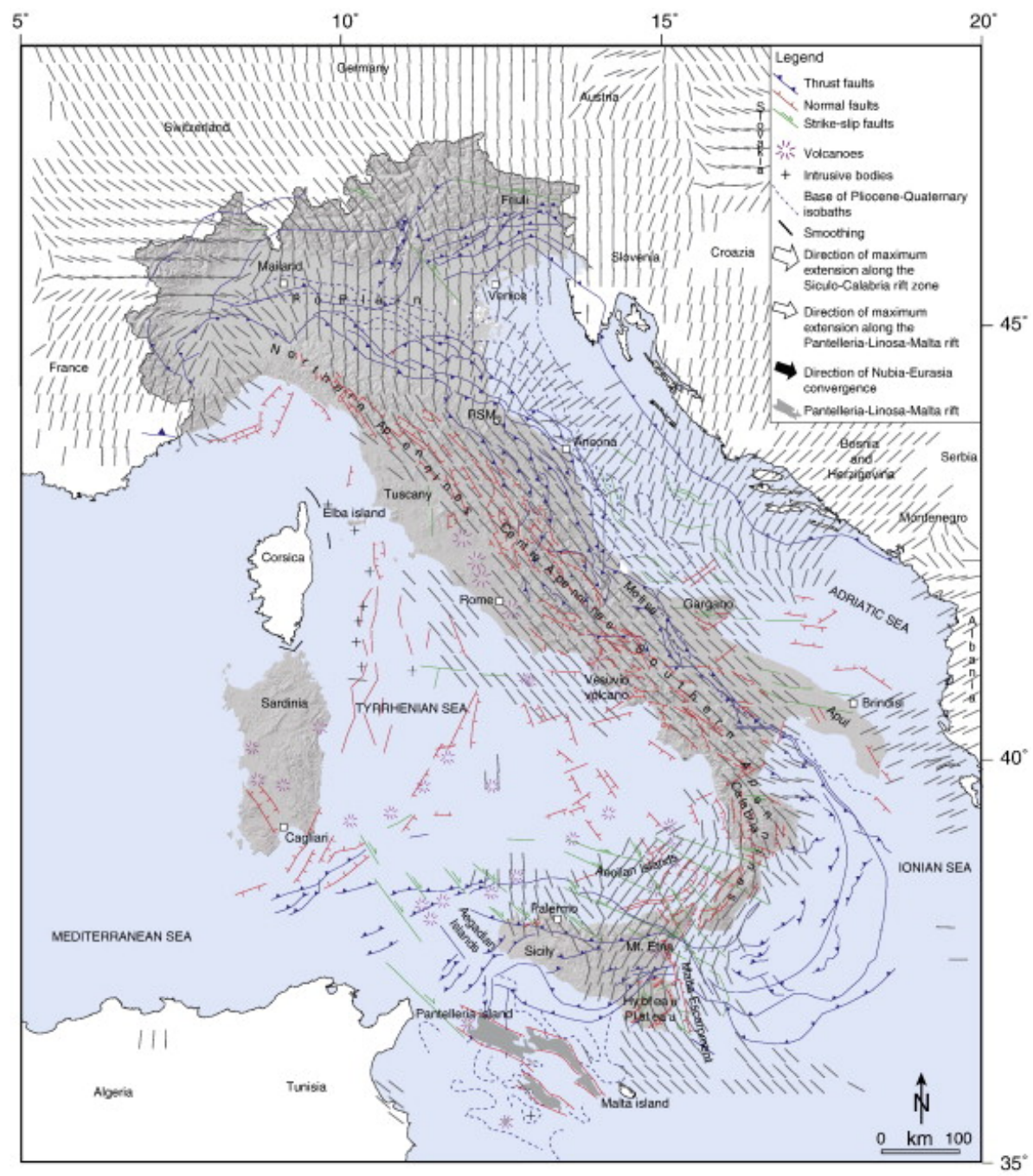

Figure 6. Comparison between the mean $S_{H}$ orientation (black line) and the structural setting in Italy (modified from Meletti et al., 2000; Galadini et al., 2001; Catalano et al., 2010; Neri et al., 2003).

geodynamic and tectonic setting of Italy, pointing out some peculiar features in four areas.

From analysis of the mean $S_{H}$ orientation, the wave-length stress pattern (dark shaded blue color with a search radius between 150 and $300 \mathrm{~km}$; Fig. 5a) and its variance $\left(<25^{\circ}\right.$ in green color in Fig. $5 \mathrm{~b}$ ), we single out that the present-day stress is well-constrained along the Apennine belt with a of $S_{H}$ orientation is NW-SE (Figs. 5 and 7) indicating that a long wave-length stress pattern is still prevailing in this area due to the African and European plate tectonic forces. This result is confirmed also from previous works (e.g. Anderson and Jackson, 1987; Montone et al., 2004; Pondrelli et al., 2002; Westaway, 1992).

The present-day state of stress of the eastern part of the $\mathrm{Al}$ pine arc shows a mean $S_{H}$ orientation from NNW-SSE to NS, a long wave-length of the stress pattern (dark shaded blue color with a search radius between 150 and $300 \mathrm{~km}$; Fig. 5a) and an associated low variance $\left(<25^{\circ}\right.$-green color; Fig. $\left.5 \mathrm{~b}\right)$. This feature is ascribed to the progressive motion of the Adria microplate and its anticlockwise rotation with respect to the Eurasian plate (Anderson and Jackson, 1987; Bressan et al., 1998, 2003; Mantovani et al., 1996). The area is characterized by a compressional stress regime, derived from focal mechanisms (Bressan et al., 2003; Perniola et al., 2004; Slejko et al., 1999; Viganò et al., 2008) and by overthrusts with a southward movement towards the Adria plate. Presently, the pre-alpine Friuli sector is uplifting, while the frontal plane is subsiding (Zanferrari et al., 1982).

On the contrary, the western part of the region shows NWSE compression as for the rest of Alpine area and western Eu- rope (Zoback, 1992; Grünthal and Stromeyer, 1992). Such behavior is in contrast with the hypothesis of a rigid rotation of the plate and might be, at least in part, explained with the occurrence of inherited structures (Bressan et al., 1998). Actually, the western part of the Alps is an active collision belt due to the convergence between Europe-Africa plates with a probable counterclockwise rotation of the indenter of the Adria in the European plate (Anderson and Jackson, 1987; Tapponnier, 1977; Vialon et al., 1989). This area (sector 1; Fig. 7a) exhibits a greater heterogeneity of the mean $S_{H}$ orientation (already revealed by Müller et al., 1992) showing a short wave-length stress pattern (Fig. 5a) with associated high variance (red color in Fig. 5b) probably governed by the bend of the thrusts (active in the outboard of the thrusts) and the coexistence of a widespread extension in the core of the western Alps revealed by earthquake analysis (Sue et al., 1999) and also linked to the local tectonic features. The extension is radial to the arcuate geometry of the belt and located between two compressive domains (Sue et al., 1999). Scattering of the mean $S_{H}$ orientation is mainly due to the considerable arcuate shape of the belt. An interesting feature is the trend in the southeastern part of this portion of the Alps where the mean $S_{H}$ orientation is deeply affected by Ivrea-Verbano structure, an exhumed mantle segment of the Adriatic microplate (Di Stefano et al., 2009; Schmid and Kissling, 2000; Schmid et al., 2005) and the convergence variance with Monferrato Arc (Fig. 7a). In turn, in the western part the mean $S_{H}$ orientation deduced from borehole breakouts is dominated by the buried thrusts below the Po Plain which interfere with 

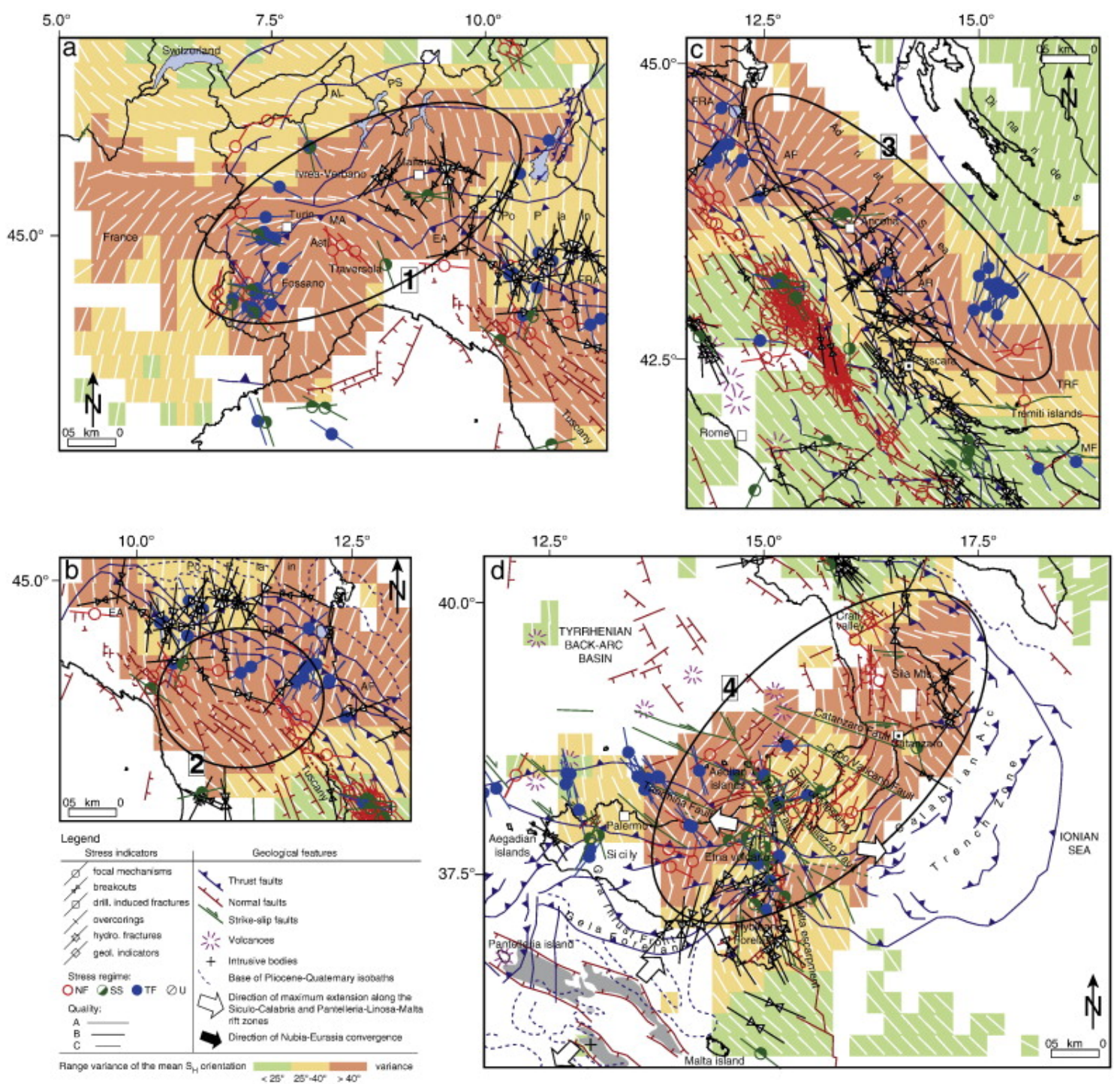

Figure 7. Four high variance zones of mean $S_{H}$ orientation: a) northwestern Italy; b) northern Tuscany; c) Adriatic offshore; 4) Sicily and southern Calabria. Comparison with the mean $S_{H}$ orientations, tectonic features and stress data records. Main structural features of Italy (modified from Consiglio Nazionale delle Ricerche, 1992 and from Neri et al., 2003). MA = Monferrato Arc; EA = Emilia Arc; FRA = Ferrara Romagna Arc; $\mathrm{AF}=\mathrm{Adriatic}$ Folds; AR = Adriatic ridge; TF = Tremiti Fault; MF = Mattinata Fault.

Alpine structures and the front of the northern part of the Apennines (Pierdominici et al., 2005). These features are composed by quaternary structures with different orientation: NE-SW Torino anticline, E-W Asti syncline, NNW-SSE Fossano anticline and NNE-SSW to N-S Traversola deformation zone (Carraro et al., 1982, 1994). The present-day stress data records of the Po Plain and the Emilia-Romagna arc exhibit a constant NNE-SSW compression regime with small rotations of $S_{H}$ related to a three arcuate thrusts systems (Monferrato, Emilia-Romagna and Ferrara arcs; Figs. 5a and 7b) that represent the front of the northern Apennines accretionary prism below the Po Plain (e.g., Burrato et al., 2003; Carminati and Vadacca, 2010; Carminati et al., 2010; Mariucci et al., 1999; Montone and Mariucci, 1999; Pierdominici et al., 2005; Pieri, 1983; Pieri and Groppi, 1981; Scrocca et al., 2007).

In sector 2 , the mean $S_{H}$ orientation is homogeneous at southwest while towards the inner part of the Apennines belt the mean $S_{H}$ orientation changes abruptly from NNW to NNE (Figs. 5a and 7b). In the Tyrrhenian part an extensional regime is prevalent, as can be seen by active normal faulting and focal mechanism solutions (Frepoli and Amato, 1997; Galadini et al., 2001; Montone et al., 1999, 2004; Pondrelli et al., 2006). In the outer part of the Apennines chain a transpressive-compressive regime is confirmed by focal mechanism solutions of earth- quakes from active thrust and strike-slip faults (Pondrelli et al., 2006,2011 ) due to a compressive deformation in the northernmost termination of the Apennines and around the buried thrusts below the Po Plain. The arcuate shapes of this portion of the chain are attributed to tectonic structures striking perpendicular to the chain with a NE-SW trending compression. In the rest of outer chain, the compressive regime is prevalent and the thrust structures show a $\mathrm{N}$ to NE trending orientation of the compressional $P$-axes, always perpendicular to the chain.

The Apennines thrust front (Fig. 7c), interpreted as the development of discrete thrust structures (Scrocca et al., 2007) is less clear in the central Adriatic Sea between Ancona and Pescara towns but it is well defined from the trend of $S_{H}$ orientation. Indeed, this region (Fig. 7c) shows a NW-SE trend of the mean $S_{H}$ orientation in intern arcs whereas the mean $S_{H}$ orientation is NE-SW-oriented in the external part of the arc, deduced by mainly compressive focal mechanism solutions. The strike-slip regime deduced from focal mechanism solution near Ancona has been interpreted with combined local forces from oroclinal bending in the regional compressional stress field (Boncio and Bracone, 2009). The scatter of the mean $S_{H}$ orientation located to southeast of Ancona town is connected to an Adriatic ridge (Fig. 7b). Some authors have interpreted this structure as structural high due to thrust-related folds and salt diapirism (e.g., 
Argnani and Frugoni, 1997; Bally et al., 1986; Calamita et al., 2003; De Alteriis, 1995; Ori et al., 1986; Scrocca, 2006). Furthermore, the evident scattered trend of mean $S_{H}$ orientation in the Po Plain and the central-northern Adriatic domain, up to north the Tremiti lineament is due to the still active northeastward flexural retreat of the subducting Adriatic lithosphere and the related frontal accretion of the Apennine prism (Scrocca et al., 2007). Moving southward, a NW orientation of mean $S_{H}$ is prevalent and is consistent with main right-lateral transfer zones EW-oriented in Gargano area. Here, the Apennines thrust front was split in correspondence with the Tremiti lithospheric transfer zone (Fig. 6b), which separated two blocks of the subducting Adria microplate (Battaglia et al., 2004; Doglioni et al., 1994; Oldow et al., 2002; Scrocca, 2006; Westaway, 1990).

The mean $S_{H}$ orientation of the Calabrian arc and in Sicily is more scattered and results in low wave-length stress pattern $(<100 \mathrm{~km}$ of search radius). The associated circular variance $\left(<25^{\circ}\right)$ indicates that in these regions the stress pattern is probably controlled third-order stress sources from active faults, local density and strength contrast that interfere with three different plate boundary forces from collision (Hyblean plateau) subduction (Calabrian arc) and back-arc spreading (Tyrrhenian Sea). Furthermore, the magmatic activities of the volcanic islands also contribute with buoyancy forces to the stress pattern (Fig. 5). In detail, in the sector 4 (Fig. 7d) the geological and structural relationships are complex and vary in the area enclosing the Calabria and eastern part of Sicily. The mean $S_{H}$ orientations are about $\mathrm{E}-\mathrm{W}$ in the upper part of the Calabria region then change from NW to a consistent NE trend (Straits of Messina) afterwards again to be NW-orientation. The Calabria and Sicily sectors are characterized by a strong tectonic activity. The main Quaternary normal faults of the Calabria region have been detected in the Sila Mts. having a NW-SE trend (Galli and Bosi, 2003), in the Crati basin with a N-S trend (e.g. Cucci and Cinti, 1998; Lanzafame and Tortorici, 1981), in the Catanzaro area with an E-W trend (Moretti, 2000), towards south a NNE-SSW trend defines the graben or half-graben basins (e.g. Galli and Bosi, 2002). The two main active quaternary normal faults in Sicily are located off-shore, the fault affecting the strait of Messina being responsible for the 1908 earthquake (Valensise and Pantosti, 1992) and the so called Malta escarpment (identified by reflection seismic profiles; Argnani et al., 2002). Minor Quaternary faults probably affect the stress pattern of Hyblean foreland (SE Sicily) with a NE-SW trend (e.g. Monaco, 1997). Indeed, the rotations of the compressional axis are due to the presence of active faults (e.g. $S_{H}$ is oriented NW-SE in the Hyblean region in agreement with tectonic structures; Ragg et al., 1999) whereas the NE trend of the mean $S_{H}$ orientation between northeast part of Sicily and Calabria seem to be consistent with the trend of the axis of the rift zone (NE-SW, in the Aeolian islands; Catalano et al., 2008, 2010) and with extension processes due to different directions and rate of motion between Sicily and Calabria (D'Agostino and Selvaggi, 2004; Hollenstein et al., 2003; Neri et al., 2005). In the central portion of the Gela thrust front, the mean $S_{H}$ orientation is NNE-SSW perpendicularly to the thrust front itsself. In the southeast of Sicily the mean $S_{H}$ orientation change from NNW (Hyblean Plateau) to NE (to north of Malta escarpment) probably due to the presence of a transfer zone (Tindari Fault; Billi et al., 2010). The extensional tectonics are still active in the southeastern corner of the Tyrrhenian Sea (i.e., to east of Tindari Fault) and along the Ionian coast of Sicily and southern Calabria (Mattia et al., 2009; Neri et al., 2003, 2005). This tectonic setting is possibly linked with backarc extension induced by residual retreat and subduction of the Ionian slab beneath the Calabrian arc (D'Agostino et al., 2008). In contrast, beneath Sicily, to the west of the Tindari Fault and Ionian Sea, tomographic images show the absence of a subducting slab (Neri et al., 2009; Piromallo and Morelli, 2003) with a prevalent NE trend of the mean $S_{H}$ orientation.

\section{Conclusions}

The present-day crustal stress pattern was analyzed on the basis of 1039 A-C quality crustal stress indicators from earthquake focal mechanism, borehole breakouts and geological fault-slip data of Italy and neighboring countries. In particular we investigated the hypothesis that the mean $S_{H}$ orientation changes with depth. For this, we investigated by a statistical approach if the mean $S_{H}$ orientation using data from greater depth $(\geq 6 \mathrm{~km})$ deviates from the ones from shallow depth $(<6 \mathrm{~km})$. The analysis shows that in most areas the mean $S_{H}$ orientation does not change with depth. Thus, data from all depth sections can be used for an analysis of the wave-length of the stress pattern and the estimation of the mean $S_{H}$ orientation on a regular grid.

Our main conclusions comprise that the mean $S_{H}$ orientation in most areas has short wave-length of $150 \mathrm{~km}$ or lower. This points out that the stress pattern in Italy is controlled to large extend by third-order stress sources due to the local effects, representing a good example of short-scale stress perturbations (e.g. stress reorientation at fault tips, lateral density contrast, topography). This is in agreement with the qualitative findings of Heidbach et al. $(2007,2010)$ who conclude that in areas with recent and ongoing geodynamic processes third-order stress sources can have a major control on the stress orientations.

\section{Acknowledgements}

This work has been conducted as part of collaboration between the Istituto Nazionale di Geofisica e Vulcanologia (Italy) and the Helmholtz-Zentrum Potsdam Deutsches GeoForschungsZentrum GFZ (Germany). SP was funded by MIUR-FIRB Project ("Research and Development of New Technologies for Protection and Defence of Territory from Natural Risks", W.P. C3 "Crustal Imaging in Italy"). Some figures were drawn using Generic Mapping Tool (Wessel and Smith, 1995) and CASMI software (Heidbach and Höhne, 2008). The authors highly appreciate the constructive remarks and comments from M. Ask (Luleå University of Technologies, Sweden) and an anonymous reviewer.

\section{References}

Anderson, H., Jackson, J., 1987. Active tectonics of the adriatic region. Geophysical Journal of the Royal Astronomical Society 91, 937-983.

Argnani, A., Frugoni, F., 1997. Foreland deformation in the Central Adriatic and its bearing on the evolution of the Northern Apennines. Annales Geophysicae 40, 771-780.

Argnani, A., Bonazzi, C., Mesc 2001 Crew, 2002. Tectonics of eastern Sicily offshore: preliminary results from the MESC 2001 marine seismic cruise. Boll. Geof. Teor. Appl. 43, 177-193.

Bally, A.W., Burbi, L., Cooper, C., Ghelardoni, R., 1986. Balanced sections and seismic reflection profiles across the Central Apennines. Memorie della Società Geoligica Italiana 35, 257-310.

Barba, S., Carafa, M.M.C., Mariucci, M.T., Montone, P., Pierdominici, S., 2010. Present-day stress-field modelling of southern Italy constrained by stress and GPS data. Tectonophysics 482 (1-4), 193-204. doi:10.1016/j.tecto. 2009.10.017.

Battaglia, M., Murray, M.H., Serpelloni, E., Bürgmann, R., 2004. The Adriatic region: an independent microplate within the Africa-Eurasia collision zone. Geophysical Research Letters 31, L09605. doi:10.1029/ 2004GL019723.

Bell, J.S., 1996. Petro Geoscience In situ stresses in sedimentary rocks (part 1): measurement techniques. Geoscience Canada 23, 85-100.

Bell, J.S., Gough, D.I., 1979. Northeast-southwest compressive stress in Alberta: evidence from oil wells. Earth and Planetary Science Letters 45, 475-482.

Billi, A., Presti, D., Orecchio, B., Faccenna, C., Neri, G., 2010. Incipient extension along the active convergent margin of Nubia in Sicily, Italy: Cefalù-Etna seismic zone. Tectonics 29 (TC4026). doi:10.1029/ 2009TC002559.

Boccaletti, M., Dainelli, P., 1982. II sistema regmatico neogenico-quatermario nell'area mediterranea: esempio di deformazione plastico-rigida postcollisionale. Memorie della Società Geoligica Italiana 24, 465-482. 
Boncio, P., Bracone, V., 2009. Active stress from earthquake focal mechanisms along the Padan - Adriatic side of the Northern Apennines (Italy), with considerations on stress magnitudes and pore-fluid pressure. Tectonophysics 476, 180-194. doi:10.1016/j.tecto.2008.09.018.

Bressan, G., Snidarcig, A., Venturini, C., 1998. Present state of tectonic stress of the Friuli area (eastern Southern Alps). Tectonophysics 292, 211-227.

Bressan, G., Bragato, P.L., Venturini, C., 2003. Stress and strain tensors based on focal mechanisms in the seismotectonic framework of the Friuli-Venezia Giulia region (Northeastern Italy). Bulletin. Seismological Society of America 93, 1280-1297.

Brudy, M., Zoback, M.D., Fuchs, K., Rummel, F., Baumgaertner, J., 1997. Estimation of the complete stress tensor to $8 \mathrm{~km}$ depth in the KTB scientific drill holes; implications for crustal strength. Journal of Geophysical Research 102, 18,453-18,475.

Burrato, P., Ciucci, F., Valensise, G., 2003. An inventory of river anomalies in the Po Plain, Northern Italy: evidence for active blind thrust faulting. Annals of Geophysics 46 (5), 865-882.

Calais, E., DeMets, C., Nocquet, J.M., 2003. Evidence for a post-3.16-Ma change in Nubia-Eurasia-North America plate motions? Earth and Planetary Science Letters 216, 8-92.

Calamita, F., Paltrinieri, W., Pelorosso, M., Scisciani, V., Tavernelli, E., 2003. Inherited mesozoic architecture of the Adria continental paleomargin in the neogene central Apennines orogenic system, Italy. Bollettino. Societa Geologica Italiana 122, 307-318.

Carminati, E., Vadacca, L., 2010. Two- and three-dimensional numerical simulations of the stress field at the thrust-front of the Northern Apennines, Italy. Journal of Geophysical Research 115, B12425. doi:10.1029/ 2010JB007870.

Carminati, E., Scrocca, D., Doglioni, C., 2010. Compaction-induced stress variations with depth in an active anticline: Northern Apennines, Italy Journal of Geophysical Research 115, B02401. doi:10.1029/ 2009 JB006395.

Carraro, F., Ferrero, E., Forno, M.G., Ricci, B., 1982. Dati preliminari sull'evoluzione neo-tettonica dell'arco delle Alpi occidentali. Nuovi contributi alla realizzazione della Carta Neotettonica d'Italia: CNR-PFG pubbl., 251, pp. 235-249.

Carraro, F., Ghibaudo, G., Giardino, M., Perotto, A., 1994. Intense deformazioni in depositi fluvio-lacustri olocenici nella media Valle d'Aosta. Atti Tic. Sc. Terra, 37, pp. 123-136.

Catalano, S., De Guidi, G., Monaco, C., Tortorici, G., Tortorici, L., 2008. Active faulting and seismicity along the Siculo-Calabrian Rift Zone (Southern Italy). Tectonophysics 453, 177-192.

Catalano, S., Romagnoli, G., Tortorici, G., 2010. Kinematics and dynamics of the Late Quaternary rift-flank deformation in the Hyblean Plateau (SE Sicily). Tectonophysics 486 (1-4), 1-14.

Chiarabba, C., Jovane, L., Di Stefano, R., 2005. A new view of Italian seismicity using 20 years of instrumental recordings. Tectonophysics 395, 251-268.

Chiarabba, C., De Gori, P., Speranza, F., 2008. The southern Tyrrhenian subduction zone: deep geometry, magmatism and Plio-Pleistocene evolution. Earth and Planetary Science Letters 268, 408-423.

Cimini, G.B., Marchetti, A., 2006. Deep structure of peninsular Italy from seismic tomography and subcrustal seismicity. Annals of Geophysics 49 (1), 331-345

Coblentz, D., Richardson, R.M., 1995. Statistical trends in the intraplate stress field. Journal of Geophysical Research 100 (B10), 20245-20255.

Consiglio Nazionale delle Ricerche, 1992. Structural Model of Italy and Gravity Map. Progetto Finalizzato Geodinamica. Quaderni de "La Ricerca Scientifica" 114 (3).

Cucci, L., Cinti, F.R., 1998. Regional uplift and local tectonic deformation recorded by the Quaternary marine terraces on the Ionian coast of northern Calabria (southern Italy). Tectonophysics 292, 67-83.

D'Agostino, N., Selvaggi, G., 2004. Crustal motion along the Eurasia-Nubia plate boundary in the Calabrian Arc and Sicily and active extension in the Messina Straits from GPS measurements. Journal of Geophysical Research 109, B11402. doi:10.1029/2004JB002998.

D'Agostino, N., Avallone, A., Cheloni, D., D'Anastasio, E., Mantenuto, S., Selvaggi, G., 2008. Active tectonics of the Adriatic region from GPS and earthquake slip vectors. Journal of Geophysical Research 113, B12413. doi:10.1029/2008JB005860.

De Alteriis, G., 1995. Different foreland basins in Italy: examples from the central and southern Adriatic Sea. Tectonophysics 252, 349-373.

Devoti, R., Riguzzi, F., Cuffaro, M., Doglioni, C., 2008. New GPS constraints on the kinematics of the Apennines subduction. Earth and Planetary Science Letters 273, 163-174. doi:10.1016/j.epsl.2008.06.031.

Dewey, J.F., Pitman, W.C., Ryan, W.B.F., Bonnin, J., 1973. Plate tectonics and the evolution of the Alpine system. Geological Society of America Bulletin 84, 3137-3180.

Dewey, J.F., Helman, M.L., Turco, E., Hutton, D.H.W., Knott, S.D., 1989. Kinematics of the Western Mediterranean. In: Coward, M.P., Dietrich, D., Park, R.G. (Eds.), Alpine Tectonics: Geological Society Special Publication, 45, pp. 265-283.

Di Stefano, R., Kissling, E., Chiarabba, C., Amato, A., Giardini, D., 2009. Shallow subduction beneath Italy: three-dimensional images of the AdriaticEuropean-Tyrrhenian lithosphere system based on high-quality $\mathrm{P}$ wave arrival times. Journal of Geophysical Research 114, B05305. doi:10.1029/ 2008JB005641.

Doglioni, C., Mongelli, F., Pieri, P., 1994. The Puglia uplift (SE Italy): an anomaly in the foreland of the Apenninic subduction due to buckling of a thick continental lithosphere. Tectonics 13, 1309-1321.

Faccenna, C., Davy, P., Brun, J.P., Funiciello, R., Giardini, D., Mattei, M., Nalpas, T., 1996. The dynamic of backarc basins: an experimental approach to the opening of the Tyrrhenian Sea. Geophysical Journal International 126, 781-795.

Faccenna, C., Jolivet, L., Piromallo, C., Morelli, A., 2003. Subduction and the depth of convection in the Mediterranean mantle. Journal of Geophysical Research 107 (B2), 2099. doi:10.1029/2001JB001690.

Faccenna, C., Funiciello, F., Piromallo, C., Rossetti, F., Funiciello, R., Giardini, D., 2004. Subduction and back arc extension in the Tyrrhenian Sea. Mem. Descr. Carta Geol. d'It. XLIV, pp. 165-184.

Frepoli, A., Amato, A., 1997. Contemporaneous extension and compression in the Northern Apennines from earthquake fault-plane solutions. Geophysical Journal International 129, 368-388.

Fuchs, K., Müller, B., 2001. World stress map of the earth: a key to tectonic processes and technological applications. Naturwissenschaften 88, 357-371.

Galadini, F., Meletti, C., Vittori, E., 2001. Major active faults in Italy: available surficial data. Geologie en Mijnbouw-Netherlands / Journal of Geosciences 80 (3-4), 273-296.

Galli, P., Bosi, V., 2002. Paleoseismology along the Cittanova fault: implications for seismotectonics and earthquake recurrence in Calabria (southern Italy). Journal of Geophysical Research 92, 1029-1048.

Galli, P., Bosi, V., 2003. The catastrophic 1638 Calabrian earthquakes (southern Italy). New insight from paleoseismologic investigation. Journal of Geophysical Research 108 (B1). doi:10.1029/ 2002JB01713.

Grünthal, G., Stromeyer, D., 1992. The recent crustal stress filed in Central Europe trajectories and finite element modelling. Journal of Geophysical Research 97, 11805-11820.

Heidbach, O., Höhne, J., 2008. CASMI - a tool for the visualization of the World Stress Map data base. Computers and Geosciences 34, 783-791. doi:10.1016/j.cageo.2007.06.004.

Heidbach, O., Barth, A., Connolly, P., Fuchs, F., Müller, B., Reinecker, J., Sperner, B., Tingay, M., Wenzel, F., 2004. Stress Maps in a Minute: The 2004 World Stress Map Release. EOS. Transactions 85, 521-529.

Heidbach, O., Reinecker, J., Tingay, M., Müller, B., Sperner, B., Fuchs, K., Wenzel, F., 2007. Plate boundary forces are not enough: second- and thirdorder stress patterns highlighted in the World Stress Map database. Tectonics 26, TC6014. doi:10.1029/2007TC002133.

Heidbach, O., Tingay, M., Barth, A., Reinecker, J., Kurfeß, D., Müller, B., 2008. 2008. The World Stress Map database release. doi:10.1594/GFZ.WSM. Rel2008.

Heidbach, O., Tingay, M., Barth, A., Reinecker, J., Kurfeß, D., Müller, B., 2010. Global crustal stress pattern based on the World Stress Map database release 2008. Tectonophysics 482, 3-15.

Hollenstein, C., Kahle, H.G., Geiger, A., Jenny, S., Goes, S., Giardini, D., 2003. New GPS constraints on the Africa-Eurasia plate boundary zone in southern Italy. Geophysical Research Letters 30. doi:10.1029/2003GL017554.

http://csi.rm.ingv.it/.

http://earthquake.usgs.gov/regional/neic/.

http://www.bo.ingv.it/RCMT/searchRCMT.html.

http://www.seismo.ethz.ch/.

http://www-app1.gfz-potsdam.de/pb53/cenec/.

Lanzafame, G., Tortorici, L., 1981. La tettonica recente della valle del fiume Crati (Calabria). Geografia Fisica e Dinamica Quaternaria 4, 11-21.

Ljundgren, C., Chang, Y., Janson, T., Christiansson, R., 2003. An overview of rock stress measurement methods. International Journal of Rock Mechanics and Mining Sciences 40, 975-989.

Malinverno, A., Ryan, W.B.F., 1986. Extension in the Tyrrhenian Sea and shortening in the Apennines as result of arc migration driven by sinking of the lithosphere. Tectonics 5, 227-245.

Mantovani, E., Albarello, D., Tamburelli, C., Babbucci, D., 1996. Evolution of the Tyrrhenian basin and surrounding regions as result of the AfricaEurasia convergence. Journal of Geodynamics 21, 35-37.

Mardia, K.V., 1972. Statistics of Directional Data: Probability and Mathematical Statistics. Academic Press, London. 357 pp.

Mariucci, M.T., Amato, A., Montone, P., 1999. Recent tectonic evolution and present stress in the northern Apennines. Tectonics 18, 108-118.

Mariucci, M.T., Montone, P., Pierdominici, S., 2008. Active stress field in central Italy: a re-vision of deep well data in the Umbria region. Annals of Geophysics 51 (2-3), 433-442.

Mariucci, M.T., Montone, P., Pierdominici, S., 2010. Present-day stress in the surroundings of 2009 L'Aquila seismic sequence (Italy). Geophysical Journal International 182, 1096-1102. doi:10.1111/j.1365-246X.2010.04679.x.

Mattia, M., Palano, M., Bruno, V., Cannavò, F., 2009. Crustal motion along the Calabro-Peloritano Arc as imaged by twelve years of measurements on a dense GPS net-work. Tectonophysics 476, 528-537.

Mazzoli, S., Helman, M., 1994. Neogene patterns of relative plate motions for Africa-Europe: some implications for recent central Mediterranean tectonics. Geologische Rundschau 83, 464-468.

Meletti, C., Patacca, E., Scandone, P., 2000. Construction of a seismotectonic model: the case of Italy. Pure and Applied Geophysics 157, 11-35. 
Monaco, C., 1997. Tettonica pleistocenica nell'area a Sud dell'Etna (Sicilia orientale). Il Quaternario 10, 395-400.

Montone, P., Mariucci, M.T., 1999. Active stress along the NE external margin of the Apennines: the Ferrara arc, Northern Italy. Journal of Geodynamics 28, 251-265.

Montone, P., Amato, A., Pondrelli, S., 1999. Stress map of Italy. Journal of Geophysical Research 104, 25595-25610.

Montone, P., Mariucci, M.T., Pondrelli, S., Amato, A., 2004. An improved stress map for Italy and surrounding regions (Central Mediterranean). Journal of Geophysical Research 109. doi:10.1029/2003JB002703.

Montone, P., Mariucci, M.T., Pierdominici, S., 2012. The Italian present-day stress map. Geophysical Journal International, DOI:10.1111/j.1365 246X.2012.05391.X

Moretti, A., 2000. Il database delle faglie capaci della Calabria: stato attuale delle conoscenze. In: Galadini, F., Meletti, C., Rebez, A. (Eds.), Ricerche de GNDT nel campo della della pericolosità sismica (1996-1999): CNR Gruppo Nazionale per la Difesa dai Terremoti, Roma, pp. 219-226.

Müller, B., Zoback, M.L., Fuchs, K., Gregersen, S., Pavoni, N., Stephansson, O., Ljunggren, C., 1992. Regional patterns of tectonic stress in Europe. Journal of Geophysical Research 97, 11783-11803.

Müller, B., Wehrle, V., Hettel, S., Sperner, B., Fuchs, K., 2003. A new method for moothing orientated data and its application to stress data. In: Ameen, M.S (Ed.), Fracture and In-situ Stress characterization of hydrocarbon reservoirs: geological Society of London spec. Publ., 209, pp. 107-126.

Neri, G., Barberi, G., Orecchio, B., Mostaccio, A., 2003. Seismic strain and seismogenic stress regimes in the crust of the southern Tyrrhenian region. Earth and Planetary Science Letters 213, 97-112.

Neri, G., Barberi, G., Oliva, G., Orecchio, B., 2005. Spatial variations of seismogenic stress orientations in Sicily, south Italy. Physics of the Earth and Planetary Interiors 148, 175-191.

Neri, G., Orecchio, B., Totaro, C., Falcone, G., Presti, D., 2009. Seismic tomogra phy says that lithospheric subduction beneath South Italy is close to die. Seismological Research Letters 80, 63-70.

Oldow, J.S., Ferranti, L., Lewis, D.S., Campbell, J.K., D'Argenio, B., Catalano, R., Pappone, G., Carmignani, L., Conti, P., Aiken, C.L.V., 2002. Active fragmentation of Adria, the north Africa promontory, central Mediterranean orogen Geology 30 (9), 779-782.

Ori, G., Roveri, M., Vannoni, F., 1986. Plio-Pleistocene sedimentation in the Apenninic-Adriatic foredeep (Central Adriatic Sea, Italy). International Association of Sedimentologists, Special Publications 8, 183-198.

Perniola, B., Bressan, G., Pondrelli, S., 2004. Changes in failure stress and stress transfer during the 1976-77 Friuli earthquake sequence. Geophysical Journal International 156, 297-306. doi:10.1111/j.1365-246X.2003. 02146.x.

Pierdominici, S., Mariucci, M.T., Montone, P., Cesaro, M., 2005. Comparison between active stress field and tectonic structures in Northern Italy, Lombardy Region. Annals of Geophysics 48 (6), 867-881.

Pierdominici, S., Mariucci, M.T., Montone, P., 2011. A study to constrain the geometry of an active fault in southern Italy through borehole breakouts and downhole logs. Journal of Geodynamics. doi:10.1016/j.jog.2011. 02.006 .

Pieri, M., 1983. Three seismic profiles through the Po Plain. Seismic Expression of Structural Styles. A Picture and Work Atlas: In: Bally, A.W. (Ed.), Am. Assoc. Pet. Geol. Studies in Geology, 15. 3.4.1/8-3.4.1/26.

Pieri, M., Groppi, G., 1981. Subsurface geological structure of the Po Plain, Italy. CNR, Progetto Finalizzato Geodinamica, $414.13 \mathrm{pp}$

Piromallo, C., Morelli, A., 2003. P wave tomography of the mantle under the Alpine-Mediterranean Area. Journal of Geophysical Research 108, 2065. doi:10.1029/2002JB001757.

Plumb, R.A., Cox, J.W., 1987. Stress directions in eastern North America determined to $4.5 \mathrm{~km}$ from borehole elongation measurements. Journal of Geophysical Research 92, 4805-4816.

Pondrelli, S., Morelli, A., Ekström, G., Mazza, S., Boschi, E., Dziewonski, A.M., 2002. European-Mediterranean regional centroid-moment tensors: 19972000. Physics of the Earth and Planetary Interiors 130, 71-101.

Pondrelli, S., Salimbeni, S., Ekström, G., Morelli, A., Gasperini, P., Vannucci, G. 2006. The Italian CMT dataset from 1977 to the present. Physics of the Earth and Planetary Interiors 159, 286-303.

Pondrelli, S., Salimbeni, S., Morelli, A., Ekström, G., Postpischl, L., Vannucci, G. Boschi, E., 2011. European-Mediterranean regional centroid moment tensor catalog: solutions for 2005-2008. Physics of the Earth and Planetary Interiors 185 (3-4), 74-81. doi:10.1016/j.pepi. 2011.01.007.

Ragg, S., Grasso, M., Müller, B., 1999. Patterns of tectonic stress in Sicily from borehole breakout observations and finite element modeling. Tectonics 18 669-685.

Reinecker, J., Tingay, M., Müller, B., Heidbach, 0., 2010. Present-day stress orientation in the Molassa Basin. Tectonophysics 482 (1-4), 129-138. doi:10.1016/j.tecto.2009.07.021.
Rosenbaum, G., Lister, G.S., 2004. Neogene and Quaternary rollback evolution of the Tyrrhenian Sea, the Apennines, and the Sicilian Maghrebides. Tectonics 23. doi:10.1029/2003TC001518.

Schmid, S.M., Kissling, E., 2000. The arc of the western Alps in the light of geophysical data on deep crustal structure. Tectonics 19 (1), 62-85.

Schmid, S., Fügenschuh, B., Kissling, E., Schuster, R., 2005. Tectonic map and overall architecture of the Alpine orogen. Eclogae Geologicae Helvetiae 97, 93-117.

Scrocca, D., 2006. Thrust front segmentation induced by differential slab retreat in the Apennines (Italy). Terra Nova 18, 154-161.

Scrocca, D., Carminati, E., Doglioni, C., Marcantoni, D., 2007. Slab retreat and active shortening along the Central-Northern Apennines. In: Lacombe, 0 . Lavé, J., Roure, F., Verges, J. (Eds.), Thrust belts and Foreland Basins: from Fold Kinematics to Hydrocarbon System: Frontiers in Earth Sciences. Springer, pp. 471-487.

Selvaggi, G., Amato, A., 1992. Subcrustal earthquakes in the northern Apennines (Italy): evidence for a still active subduction? Geophysical Research Letters 19, 2127-2130.

Slejko, D., Neri, G., Orozova, I., Renner, G., Wyss, M., 1999. Stress field in Friuli (NE Italy) from fault plane solutions of activity following the 1976 main shock. Bulletin. Seismological Society of America 89, 1037-1052.

Sperner, B., Müller, B., Heidbach, O., Delvaux, D., Reinecker, J., Fuchs, K., 2003. Tectonic stress in the Earth's crust: advances in the World Stress Map project. New insights in structural interpretation and modelling: In: Nieuwland, D.A. (Ed.), Special Publication: London, Geological Society, vol. 212, pp. 101-116.

Sue, C., Thouvenor, F., Fréchet, J., 1999. Widespread extension in the core of the western Alps revealed by earthquake analysis. Journal of Geophysical Research 104 (B11), 25611-25622.

Tapponnier, P., 1977. Evolution tectonique du système alpine en Méditerranée: Poinçonnement et écrasement rigide-plastique. Bulletin de la Societe Geologique de France 7, 437-460.

Tingay, M., Müller, B., Reinecker, J., Heidbach, O., Wenzel, F., Flecknstein, P., 2005. Understanding tectonic stress in the oil patch: the World Stress Map Project. The Leading Edge 24 (12), 1276-1282.

Valensise, G., Pantosti, D., 1992. A 125 Kyr-long geological record of seismic source repeatability: the Messina Straits (southern Italy) and the 1908 earthquake (Ms 71/2). Terra Nova 4, 472-483.

Vialon, P., Rochette, P., Ménard, G., 1989. Indentation and rotation in the western Alpine arc. In: Coward, M.P., Dietrich, D., Park, R.G. (Eds.), Alpine Tectonics: Geological Society Special Publication, 45, pp. 329-338.

Viganò, A., Bressan, G., Ranalli, G., Martin, S., 2008. Focal mechanism inversion in the Giudicarie-Lessini seismotectonic region (Southern Alps, Italy): insights on tectonic stress and strain. Tectonophysics 460, 106-115.

Wessel, P., Smith, W.H.F., 1995. New version of the generic mapping tool released. EOS Trans. AGU 329 URL: gmt.soest.hawaii.edu.

Westaway, R., 1990. Present-day kinematics of the plate boundary zone between Africa and Europe, from the Azores to the Aegean. Earth and Planetary Science Letters 96, 393-406.

Westaway, R., 1992. Seismic moment summation for historical earthquakes in Italy: Tectonic implications. Journal of Geophysical Research 97, 15,43715,464

Zanferrari, A., Bollettinari, G., Carobene, L., Carton, A., Carulli, G.B., Castaldini, D., Cavallin, A., Panizza, M., Pellegrini, G.B., Pianetti, F., Sauro, U., 1982. Evoluzione neotettonica dell' Italia Nord Orientale. Memorie di Scienze Geologica $35,355-376$.

Zang, A., Stephansson, O., 2010. Stress Field of the Earth's Crust. Springer Ed. pp. 322, with DVD-ROM, doi:10.1007/978-1-4020-8444-7.

Zoback, M.L., 1992. First- and second-order patterns of stress in the litosphere: the World Stress Map Project. Journal of Geophysical Research 97 11703-11728.

Zoback, M.L., Zoback, M.D., 1980. State of stress in conterminous United States. Journal of Geophysical Research 85, 6113-6156

Zoback, M.L., Zoback, M.D., 1989. Tectonic stress field of the continental United States. Geological Society of America Memoir 172, 523-539.

Zoback, M.D., Zoback, M.L., 1991. Tectonic stress field of North America and relative plate motions. In: Slemmons, D.B., Engdahl, E.R., Zoback, M.D. Blackwell, D.D. (Eds.), Neotectonics of North America: Geological Society of America, Boulder, Colorado, pp. 339-366.

Zoback, M.D., Moos, D., Mastin, L., Anderson, R.N., 1985. Wellbore breakouts and in situ stress. Journal of Geophysical Research 90, 5523-5530.

Zoback, M.L., Zoback, M.D., Adams, J., Assumpção, M., Bell, S., Bergman, E.A., Blümling, P., Brereton, N.R., Denham, D., Ding, J., Fuchs, K., Gay, N., Gregersen, S., Gupta, H.K., Gvishiani, A., Jacob, K., Klein, R., Knoll, P., Magee, M., Mercier, J.L., Müller, B.C., Paquin, C., Rajendran, K., Stephansson, O., Suarez, G., Suter, M., Udias, A., Xu, Z.H., Zhizhin, M., 1989. Global patterns of tectonic stress. Nature 341, 291-298. doi:10.1038/341291a0. 